University of South Florida

DIGITAL COMMONS

Digital Commons @ University of

@ UNIVERSITY OF SOUTH FLORIDA

South Florida

The Inside, Outside, and Upside Downs of

Children's Literature: From Poets and Pop-ups

to Princesses and Porridge

Teaching and Learning

$1-1-2016$

\title{
Chapter 12: Banned and Burned: Why Worry? It's Just Kiddie Lit
}

Jenifer Jasinski Schneider

University of South Florida, jschneid@usf.edu

Follow this and additional works at: https://digitalcommons.usf.edu/childrens_lit_textbook

Part of the Education Commons

\section{Recommended Citation}

Schneider, Jenifer Jasinski, (2016). Banned and Burned: Why Worry? It's Just Kiddie Lit. In The Inside, Outside, and Upside Downs of Children's Literature: From Poets and Pop-ups to Princesses and Porridge (p. 324-346). http://dx.doi.org/10.5038/9780977674411.ch12

This Book Chapter is brought to you for free and open access by the Teaching and Learning at Digital Commons @ University of South Florida. It has been accepted for inclusion in The Inside, Outside, and Upside Downs of Children's Literature: From Poets and Pop-ups to Princesses and Porridge by an authorized administrator of Digital Commons@ @niversity of South Florida. For more information, please contact digitalcommons@usf.edu. 


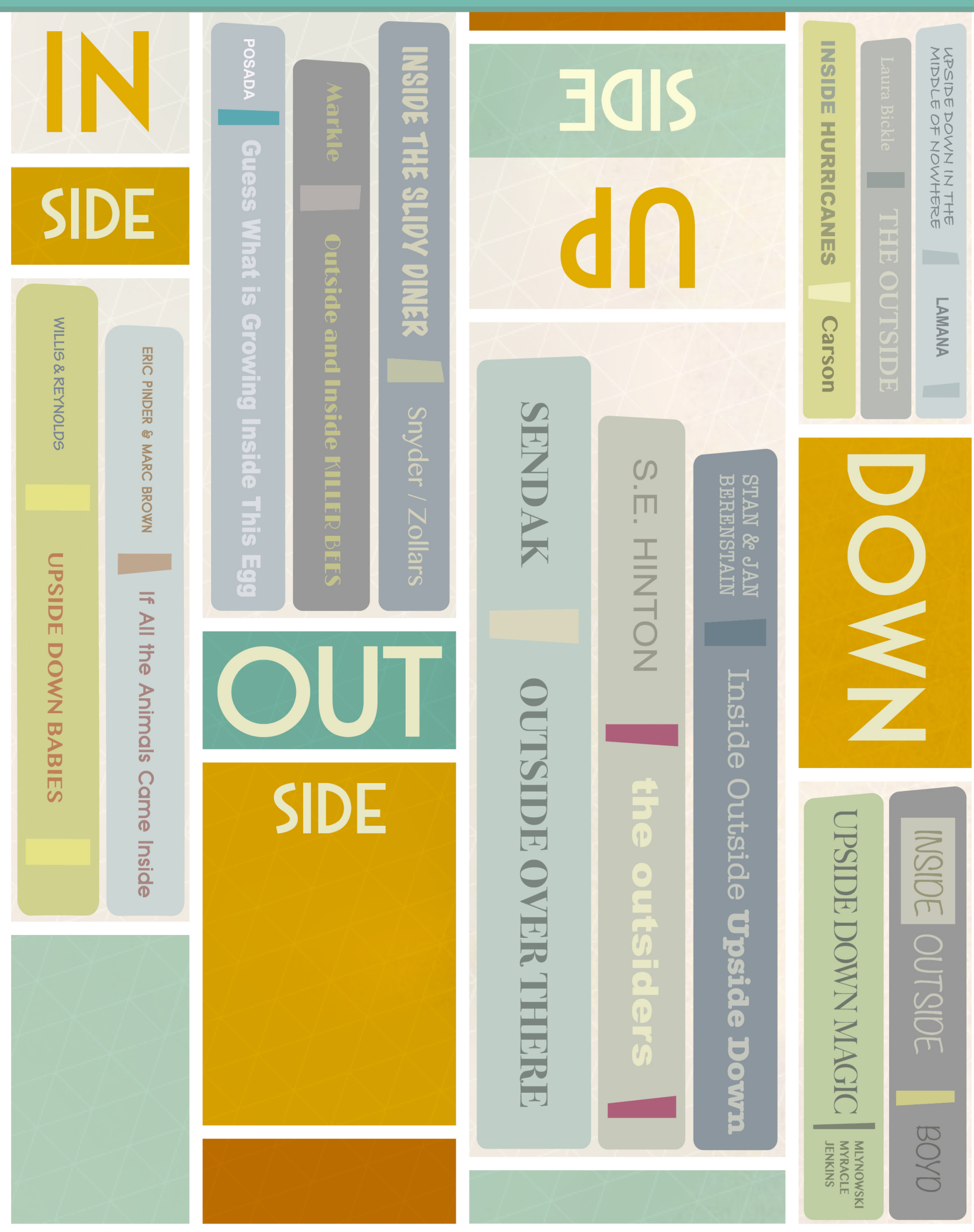

\section{THE INSIDE, OUTSIDE, AND UPSIDE DOWIS From Poets and Pop-ups to OF CHILDREN'S LITERATURE Princesses and Porridge}




\section{The Inside, Outside, and Upside Downs of Children's Literature: From Poets and Pop-ups to Princesses and Porridge}

Jenifer Jasinski Schneider, Ph.D. 
Copyright

Published by The University of South Florida Library, 4202 E. Fowler Avenue, Tampa, FL 33620.

Copyright (C2016 by Jenifer Jasinski Schneider. All rights reserved.

\section{(c) $(1) \odot$}

This work is licensed under a Creative Commons Attribution-NonCommercial-NoDerivatives 4.0 International License.

Author and Editor in Chief: Jenifer Jasinski Schneider

Editorial Director: Monica Metz-Wiseman

Media Project Manager and Producer: Christine Brown

Video Producers and Editors: Jared Brown, Jason Su, Ian Crenshaw, Jessica Brennen,

Diana Trueman, Jeremy Willis

Art Director: Stephanie Rivera

Illustrators and Multimedia Designers: William Tillis and Elise Michal

Copyright Coordinator: LeEtta M. Schmidt

Open-Access Editor: Jason Boczar

Editorial Manager: Carol Ann Borchert

Editorial Project Manager: Chelsea Johnston

Cover image book credits:

Upside Down Babies by Jeanne Willis and Adrian Reynolds (C)2013 Andersen Press; If All the Animals

Came Inside by Eric Pinder and Marc Tolon Brown (C)2012 Little, Brown and Company; Guess What Is Growing Inside This Egg by Mia Posada (C2007 Millbrook Press; Outside and Inside Killer Bees by Sandra Markle (C)2004 Walker \& Co.; Inside the Slidy Diner by Laurel Snyder and Jaime Zollars (C)2008 Tricycle Press; Outside Over There by Maurice Sendak (C)1989 HarperCollins; The Outsiders by S.E. Hinton, original cover art by Robert Hunt (C1967 Viking Press. Mass Market edition (C1997 Speak; Inside Outside Upside Down by Stan and Jan Berenstain (C1968 Random House; Upside Down Magic by Sarah Mlynowski, Lauren Myracle, and Emily Jenkins (C)2015 Scholastic Press; Inside Outside by Lizi Boyd (C)2013 Chronicle Books; Inside Hurricanes by Mary Kay Carson (C)2010 Sterling; The Outside by Lauren Bickle (C)2013 Houghton Mifflin Harcourt; Upside Down in the Middle of Nowhere by Julie T.

Lamana (C)2014 Chronicle Books.

Library of Congress Cataloging-in-Publication Data

Schneider, Jenifer Jasinski, 1968-

The Inside, Outside, and Upside Downs of Children's Literature: From Poets and Pop-ups to Princesses and Porridge / Jenifer Jasinski Schneider.

ISBN- 978-0-9776744-1-1 eBook

ISBN- 978-0-9776744-2-8 print

The Internet addresses listed in the text were accurate at the time of publication. 


\section{TEXTUAL TENDENCEES AND OPEN AND CLOSE READINGS}

\section{SECTION 3}




\section{CHATER BANNED AND BURNED: WHY WORRY? IT'S JUST KIDDIE LIT}

12

[CHLDREN, BANNED BOOKS, AND THE RIGHT TOREAD]

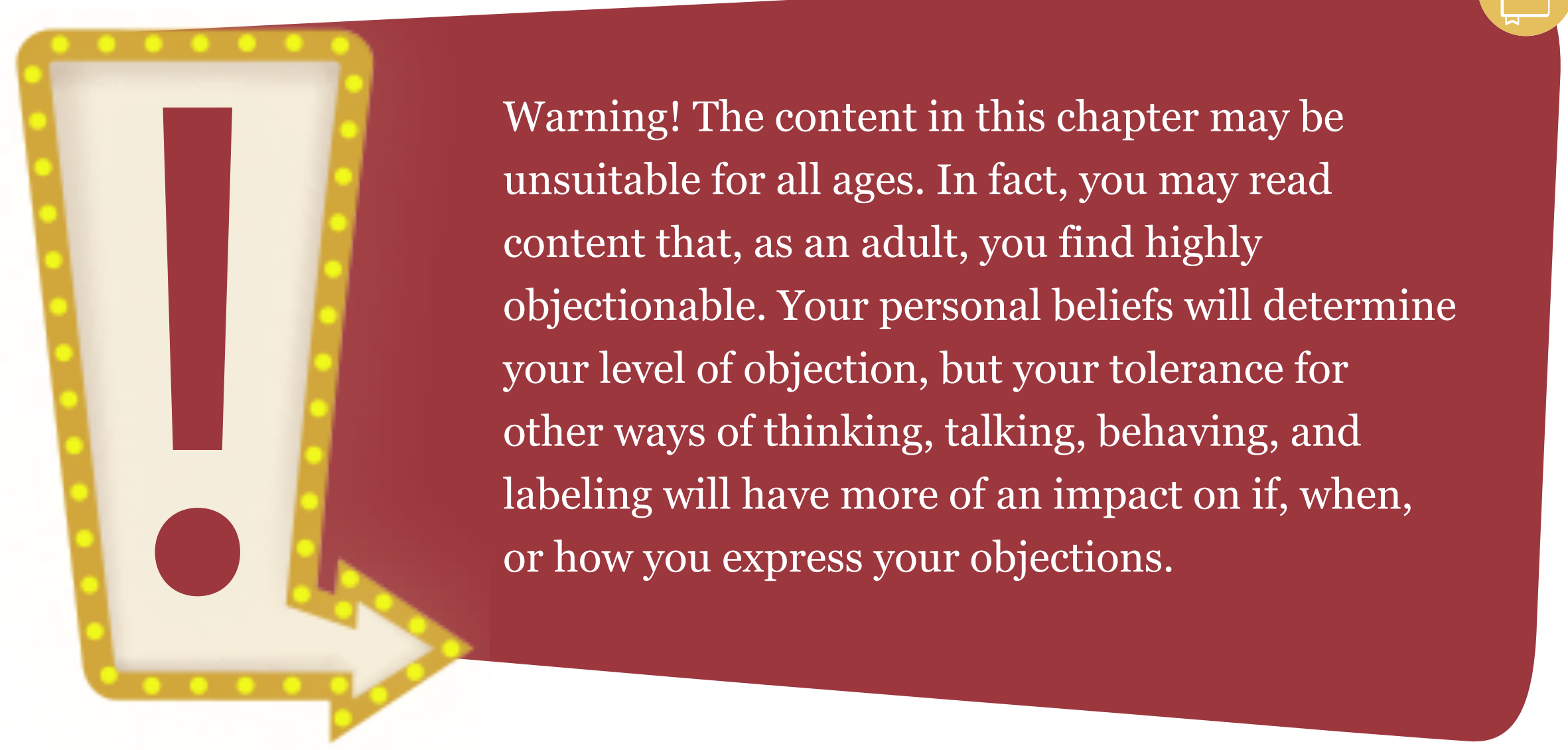

If you don't want to read a list of curse words or offensive terms used in children's literature, skip the next page. 
Are you offended by words such as fuck, bitch, fag, lez, or whore?

Let's take it down a notch and try the following: snot, butt, booger, fart, or burp?

If penis or vagina make you feel uncomfortable, how about caca, pee pee, tinkle, and poo poo?

Wait, I'm not done. What do you think about names for groups of people from various ethnicities or regions? People who might be described as "off the boat”: Dago, Polak, Spic, or Yank? Are these too old-fashioned?

OK, let's try some other old-fashioned words that are currently used: nigger, redskin, wetback, cracker.

Too harsh? Would you use the following: illegals,

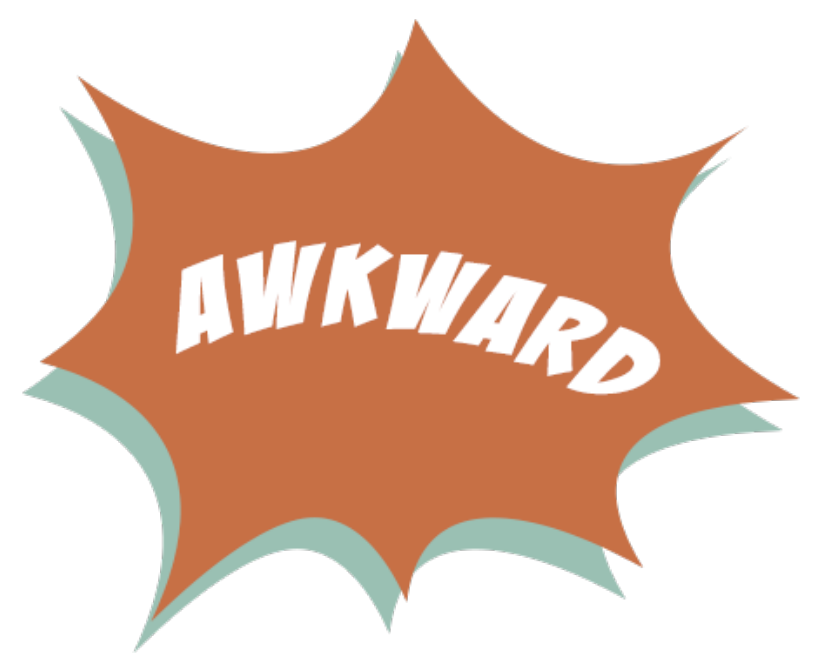
aliens, berry pickers, border jumpers?

Here are a just a few more labels: feminist, hetero, trans, Nazi, Confederate, terrorist, Christian, atheist, Muslim, Jew, wizard, witch?
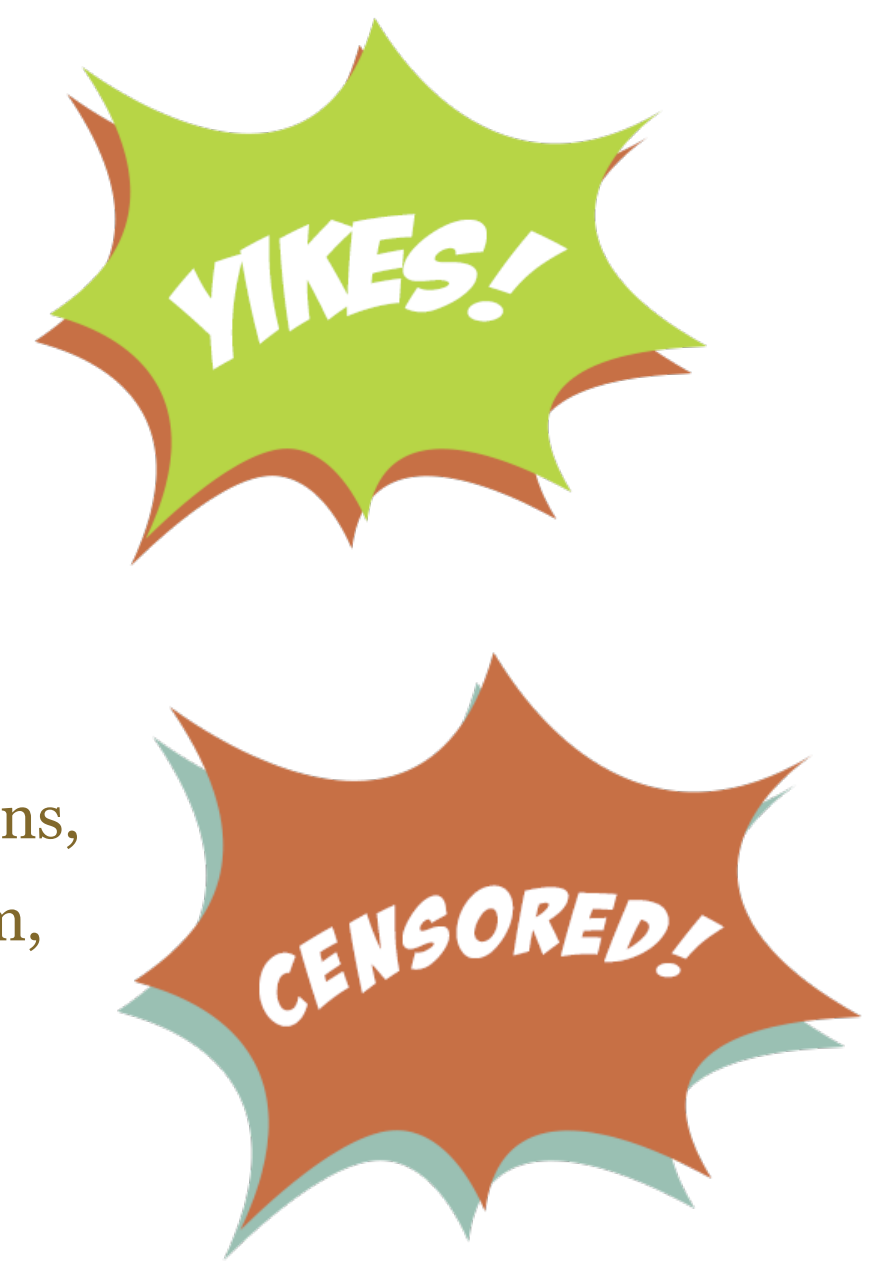
As I mentioned, your personal beliefs dictate your level of offense or comfort with the previous terms. You might hear some of these words daily or read them across text sources. Your reactions to these terms are personal and may be connected to your spiritual, moral, ethical, or individual beliefs; yet the terms carry pervasive meanings that sort and label people or objects. The terms, and the people they categorize, exist in real life. They also exist in children's and young adult literature (Click here for examples-Figure 12.1).

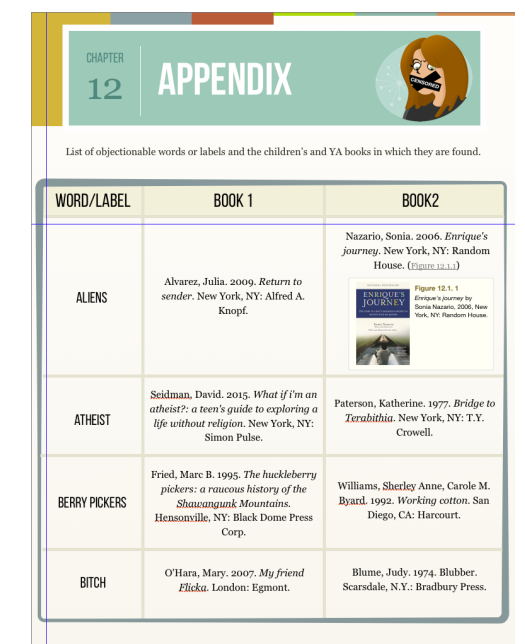

Figure 12.1

Click thumbnail for examples.

Bad words are everywhere. Here is just one example in daily life: http://www.esquire.com/news-politics/news/a29318/redskin-name-update/

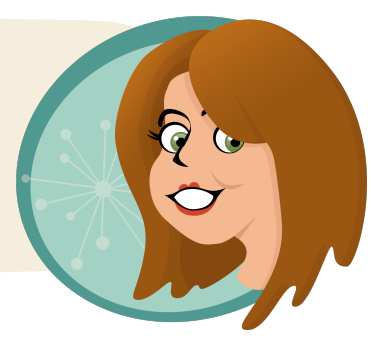

The big question is this: how do you feel about children reading objectionable words?

Are these words okay for teenagers to read?

If words are used in our homes and in society, why should children's books exclude the same concepts and words?

Where do your feelings end and the rights of others begin?

Can you accept difference even when you profoundly disagree?

Welcome to Banned Books! The place in which opinions, beliefs, morals, values, and judgments bump up against freedom, difference, rights, responsibilities, and positions. Although you will read some of the actual "banned" books that correspond to this chapter, the issues reach far beyond the books themselves. Critiquing, selecting, purchasing, displaying, censoring, and banning books are behaviors that reflect views about childhood and children, a child's right to read, a parent's right to parent, an author's freedom of speech, the role of libraries and librarians in providing equitable access to information, and the necessity of intellectual freedom as a basic right in a democratic society. 


\section{Most Wanted}

Across children's and young adult literature there are some high-profile offenders who consistently push the boundaries of what is acceptable for children to read. For example, Judy Blume is notorious for writing about real life situations, including sex, using explicit terms and language (Figure 12.2). Similarly, David Levithan writes fictional stories about the lives of teenagers with a particular focus on characters that are gay (Figure 12.3). Other authors, such as Alvin Schwartz, write scary books that feature supernatural events, mythical monsters, and evil beings that engage in violent and disturbing acts (Figure 12.4). And awardwinning authors, such as Phillip Pullman, push boundaries with cultural and religious critiques underlying their texts (Figure 12.5). Provocative books garner quick and intense attention for controversial content. However, there is one author and one book series that draws surprising and consistent protest.

What serial offender is more "unsuitable for the age group" than a book that features a man and woman who engage in bondage and sadomasochistic sex?

What cartoon character is more destructive
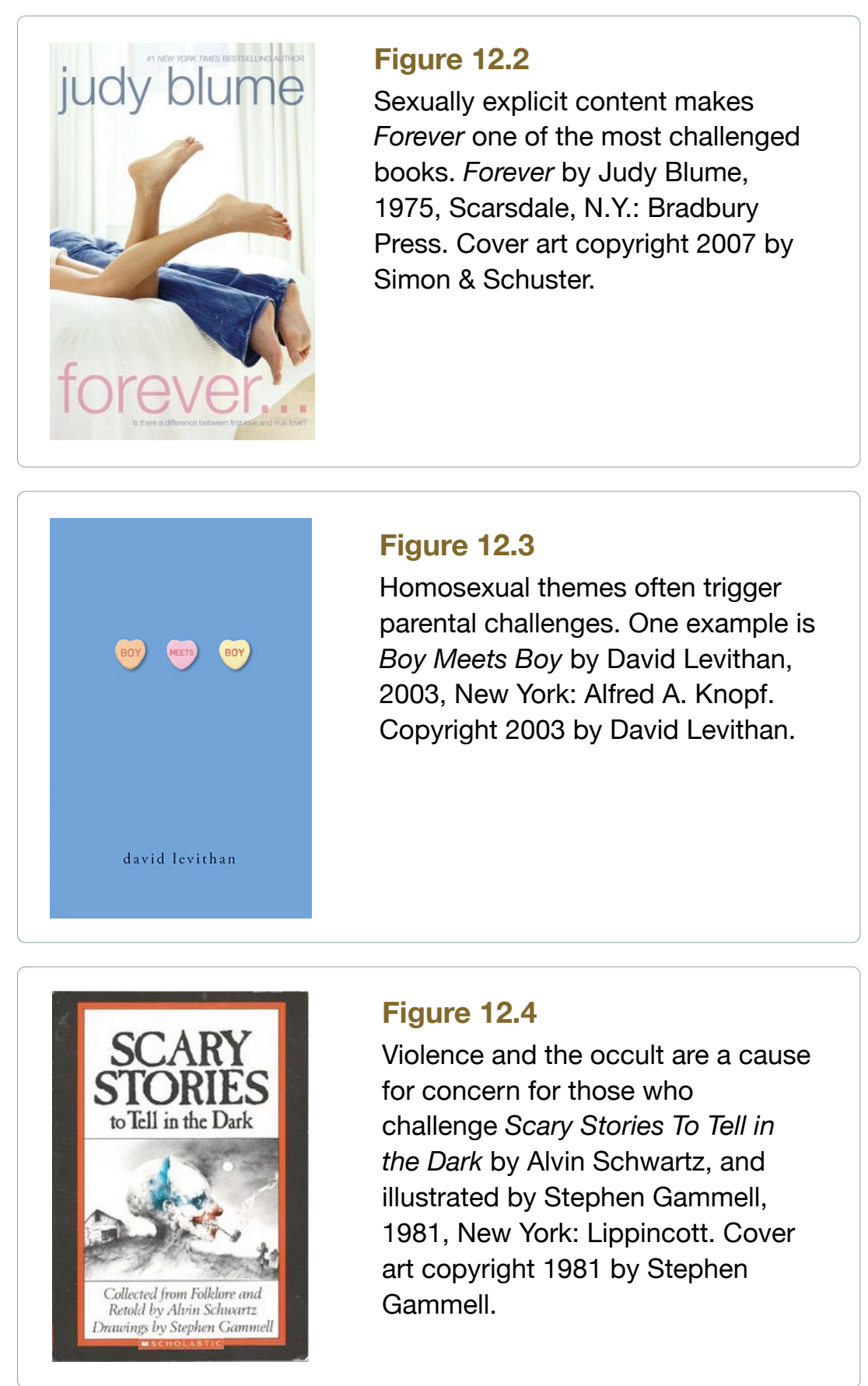

Figure 12.4

Violence and the occult are a cause for concern for those who challenge Scary Stories To Tell in the Dark by Alvin Schwartz, and illustrated by Stephen Gammell, 1981, New York: Lippincott. Cover art copyright 1981 by Stephen Gammell.

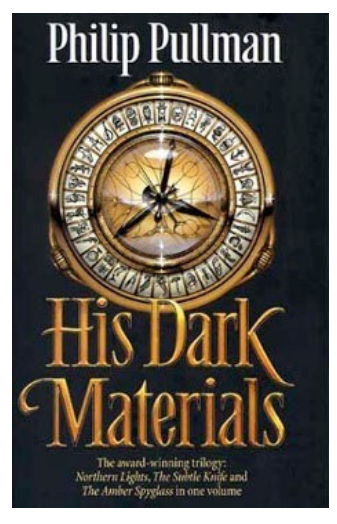

Figure 12.5

Religious groups often challenge His Dark Materials by Philip Pullman, 2007, New York: Alfred A. Knopf. Copyright 2007 by Philip Pullman.

than a male protagonist with mommy issues and his mentally disturbed stalker?

Who is more damaging to youth than a weak female protagonist in love with a "Prince Charming” who dominates her? 


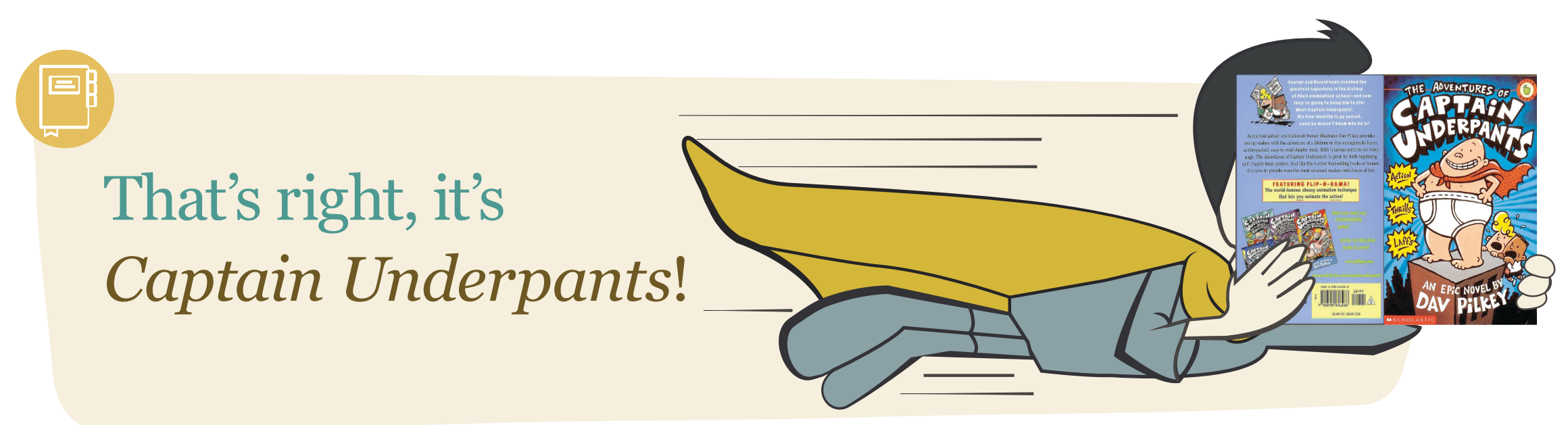

Drawing loathe and contempt from people across the US, Captain Underpants beat out Fifty Shades of Gray as the most challenged book in 2012 and 2013 and it continues to appear on frequently challenged lists (http://www.ala.org/bbooks/).

Let's take a look at Captain Underpants

(Figure 12.6)-a villainous superhero featured in a book filled with "disrespectful" dialogue, bodily functions, and men's underwear.

Captain Underpants is a book that is challenged for teaching children to question authority, to recognize that bullies come in all sizes (including adult), and to value the imagination over societal rules. Most people love it; some people hate it. You decide.
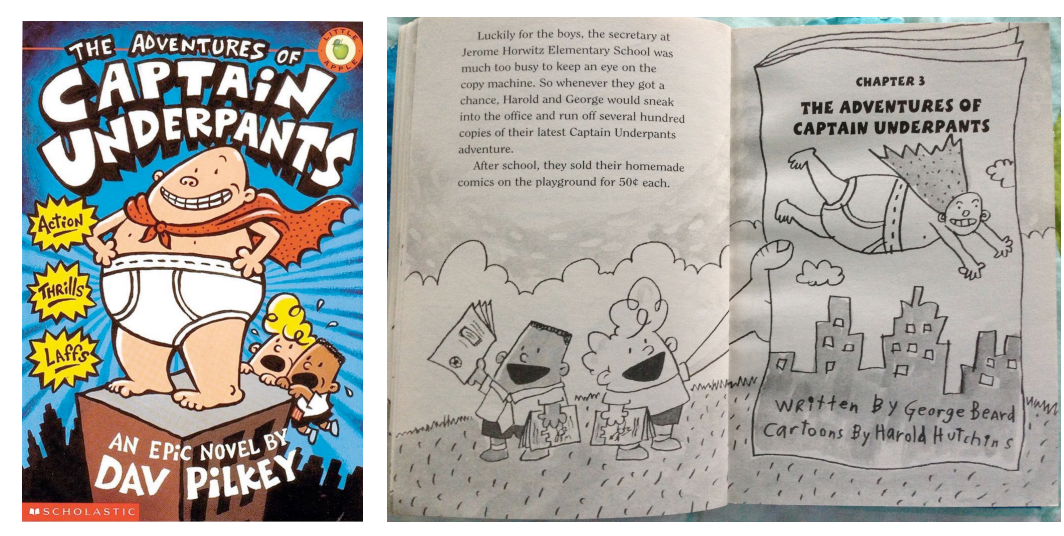

Figure 12.6 \& 12.7

George and Harold disobey school rules and undermine authority in The Adventures of Captain Underpants: An Epic Novel by Dav Pilkey, 1997, New York: Blue Sky Press.

Dav Pilkey once said: I guess I really shouldn't be surprised that my Captain Underpants series continues to top banned books lists around the world. After all, my very first Captain Underpants stories were "banned" by my second grade teacher. http://www.theguardian.com/childrens-books-site/2015/aug/31/banned-books-captainunderpants-dav-pilkey

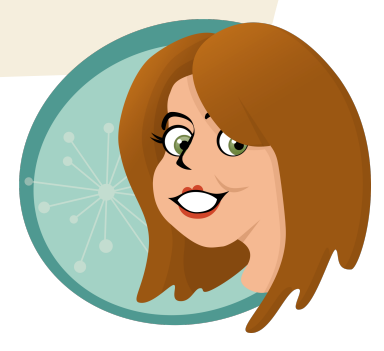




\section{Read The Adventures of Captain Underpants.}

Why is Captain Underpants so frequently challenged? In a nutshell, the main characters dislike school and they disrupt and disturb the people who run the school (Figure 12.7). In addition, the main characters disrupt and disturb the students (nerds) who do well in school. The boys, George and Harold, act badly. Parents and library patrons reject the content because they do not want children to emulate George and Harold. However, character emulation is complex. The mediating factors that create the conditions for emulation exist within the person, not the book character. According to Cohen (2001):

Identification is an imaginative process through which an audience member assumes the identity, goals, and perspective of a character... It is fairly clear that different types of media and media texts promote different responses from audiences (e.g., film vs. television, print vs. visual, first-person vs. third-person narration, and narrative texts vs. nonnarrative texts), but it is equally probable that there is variance in the responses of different groups to a given text (differentiated by social groups and psychological variables). Thus, a comprehensive theory of identification will necessarily incorporate propositions about texts and audiences (p. 261).

Parents have every right to raise their children in ways that match their personal beliefs (as long as those beliefs are in keeping with the law). There is some research and anecdotal evidence that youth may emulate characters from books, television, and video games (e.g., Strouse \& Troseth, 2008). However, the research and anecdotal evidence must be considered in the context of the whole child (Dubow, Huesmann, \& Boxer, 2009; Ferguson, 2013). Exposure to domestic violence has effects on a person, but those effects are different when the violence is experienced in real life or experienced through video games. Additionally, exposure to detrimental events (violence, trauma, poverty) can be mediated by other intervening circumstances. Take, for example, copycat crimes. Most people do not engage in copycat crimes. It is not the mere exposure to violence that begets violence; there are other factors at play.

The assumption of traditional character educators that children build moral literacy from reading or hearing moral stories is challenged based on research findings. First, research in text comprehension indicates that readers do not understand texts the same way due to differences in reading skill and background knowledge. Second, moral comprehension research indicates that moral arguments are understood differently based on differences in moral schema development. Third, moral texts (e.g., that contain embedded moral reasoning) are understood and distorted differently by readers with different moral schemas. Fourth, children do not extract moral story themes as intended by the writer (Narvaez, 2002, p. 155). 
For further elaboration on the reasons Captain Underpants is challenged, read http://www.businessinsider.com/why-captainunderpants-is-the-most-banned-book-in-america-2013-9

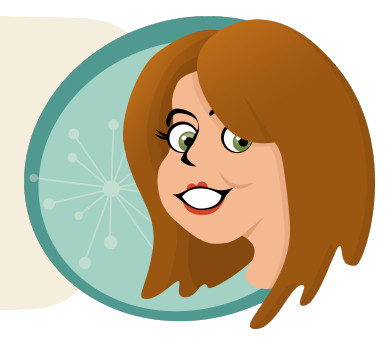

In addition to the proposal that Captain Underpants characters function as bad influences, some people challenge the books for their lack of literary qualities. Certainly, the Captain Underpants series is written for elementary aged children. The plots are funny and entertaining. Many individuals believe the books are perfect for boys, but girls enjoy the series as well. However, not all boys like the stories. Neither do all girls.

Here is one response to the question-- Why are parents opposed to a book that gets young kids (especially boys) excited about reading? Read: One Nation, Underpants http://www.slate.com/articles/arts/family/2012/og/ dav pilkey s captain underpants books why kids love them and parents should make peace with them_html

There aren't "boy" books or "girl” books. There are books.

There aren't "boy" colors/toys/sports or "girl” colors/toys/ sports. Let's go for equal opportunity and access.

Captain Underpants is no magical potion for struggling readers either. As discussed in a previous chapter, the right book needs to get into the right hands at the right time. The genre of "silly" fiction and comic-book illustration is not a perfect match for everyone. But the book series is humorous and it is different than most school reading that is selected by teachers who are one, two, or even three generations older than the targeted Second to Fourth-Grade reader. In other words, Dav Pilkey writes books for his Second Grade self-a child who struggled with learning to read (http://www.publishersweekly.com/pw/by-topic/childrens/childrensbook-news/article/67784-dav-pilkey-wants-to-give-you-superpowers.html).

For the most part, people are incredulous when they discover that Captain Underpants is one of the most challenged books. They feel the books are harmless. I agree. But what if I did not agree? Who gets to decide? 


\section{The Right to Read}

There are layers in the decision-making process when it comes to a child's right to read. At the macro level, youth who live in the United States have First Amendment rights.

\section{Amendment I}

Congress shall make no law respecting an establishment of religion, or prohibiting the free exercise thereof; or abridging the freedom of speech, or of the press; or the right of the people peaceably to assemble, and to petition the Government for a redress of grievances. (Retrieved from http://www.archives.gov/exhibits/ charters/bill of rights transcript.html)

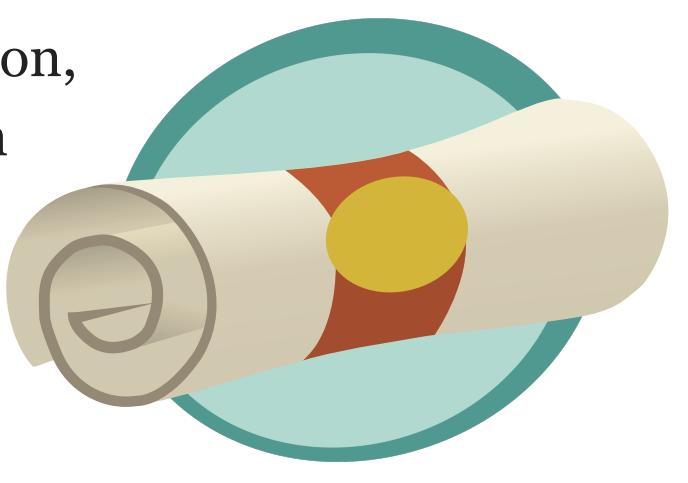

First Amendment protections apply to all youth in the context of their homes, their schools, and in public spaces. First Amendment rights also apply to literature and other media. The Supreme Court continues to operate by the following mantra: "It can hardly be argued that either students or teachers shed their constitutional rights to freedom of speech or expression at the schoolhouse gate" (Tinker v Des Moines Independent School District, 393 U.S. 503 (1969), p. 506.) However, the First Amendment seems to require Supreme Court interpretation when it comes to minors.

\section{Supreme Court Rulings}

In several cases, the Supreme Court of the United States has ruled on youth's rights to read or view material that might be considered objectionable. In the case of Erznoznik vs. Jacksonville, Richard Erznoznik, a drive-in movie theater manager, was charged with violating a city ordinance that prohibited the showing of movies containing nudity if the films were visible from public streets. The Supreme Court struck down the Jacksonville law stating that the state could not

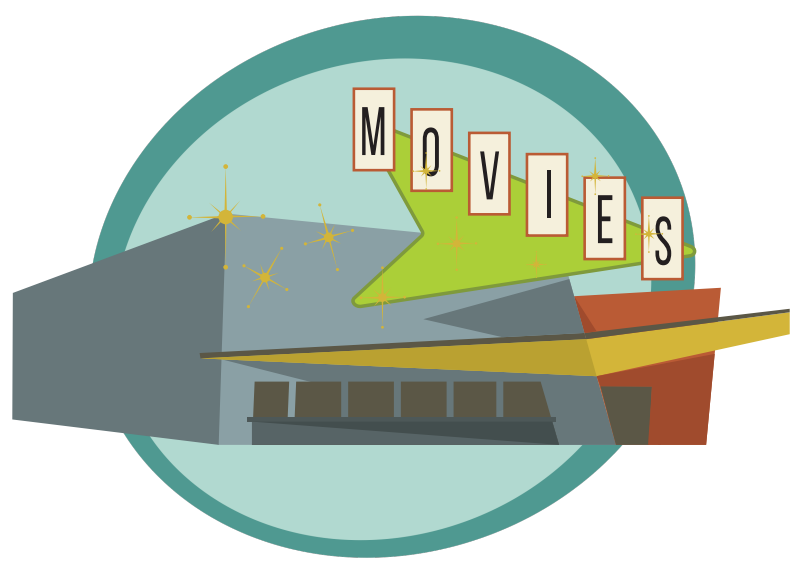
be the arbiters of what is "offensive" and the state could not single out one form of media or one type of content.

Minors are entitled to a significant measure of First Amendment protection, and only in relatively narrow and well-defined circumstances may government bar public dissemination of protected materials to them... Speech that is neither obscene as to youths nor subject to some other legitimate proscription cannot be suppressed solely to protect the young from ideas or images that a legislative body thinks unsuitable for them.

Erznoznik v. City of Jacksonville, 422 U.S. 205, 212-14 (1975). 
In Board of Education v. Pico, 457 U.S. 853 (1982), The Island Trees Union School District in New York removed several books from school libraries because the school board members determined the books were inappropriate. The court ruled that school officials could not remove books based on the ideas contained within.

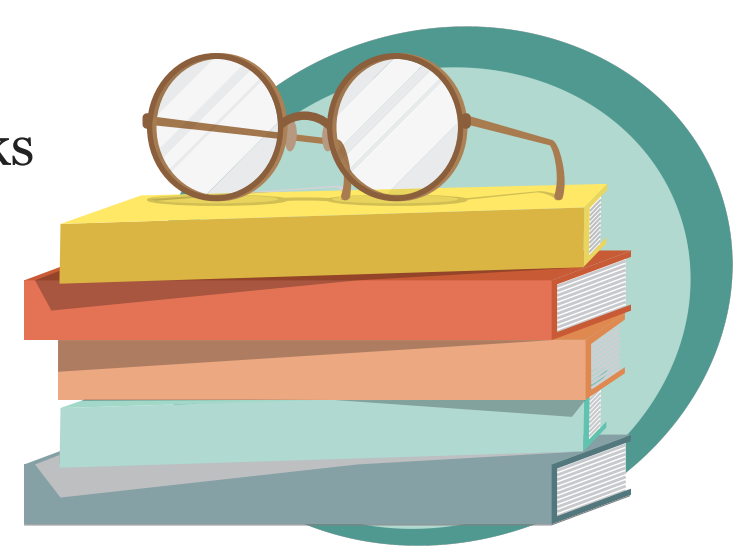

The Court has long recognized that local school boards have broad discretion in the management of school affairs.... At the same time, however, we have necessarily recognized that the discretion of the States and local school boards in matters of education must be exercised in a manner that comports with the transcendent imperatives of the First Amendment.

Board of Education v. Pico, 457 U.S. 853 (1982, pp. 864-5).

However, the Court has also ruled to limit access to materials if they are viewed as obscene. In other words, controversial ideas fall under the protection of the First Amendment, but youth need to be "protected" when the content is "obscene."

Currently, obscenity is evaluated by federal and state courts alike using a tripartite standard established by Miller v. California 413 U.S. 15 (1973). The Miller test for obscenity includes the following criteria: (1) whether 'the average person, applying contemporary community standards' would find that the work, 'taken as a whole,' appeals to 'prurient interest' (2) whether the work depicts or describes, in a patently offensive way, sexual conduct specifically defined by the applicable state law, and (3) whether the work, 'taken as a whole,' lacks serious literary, artistic, political, or scientific value.

(Retrieved from https://www.law.cornell.edu/wex/obscenity) 
For previous generations, "obscene" materials were curated by librarians, teachers, or store owners who often served as gatekeepers. Sometimes editors and publishers altered texts to conform to societal expectations. Sometimes the authors fought back (Video 12.1).

Video 12.1 Authors Fight Back: Censorship and Editorial Control in My Brother Sam is Dead http://www.kaltura.com/tiny/swt56

\section{AUTHORS FIGHT BACK: CENSORSHIP \& EDITORIAL CONTROL}

IN MY BROTHER SAM IS DEAD

BY JAMES LINCOLN COLLIER \& CHRISTOPHER COLLIER

\section{WITH MELANIE GRIFFIN}

\section{THE INSIDE, OUTSIDE, AND UPSIDE DOWNS $\mid$ From Poets and Pop-ups to Princesses}

OF CHILDREN'S LITERATURE

With the advent of digital media and the networked capabilities of the Internet, access to information, books, videos, and images is more easily obtained by youth. In order to protect children from obscene materials, some attempts have been made to restrict transmissions. For example, in 1996 Congress passed the Telecommunications Act and with it some legislators tried to include the Communications Decency Act (CDA) which attempted to restrict pornography. The Supreme Court rejected the CDA as overly broad. In response, Congress passed the Child Online Protection Act (COPA).

The ACLU again filed suit, which became Ashcroft v. Civil Liberties Union (oo-1293) 535 U.S. 564 (2002) 217 F.3d 162 (“ACLU II”). Aschcroft upheld the Constitutionality of COPA and deemed its use of "community standards' to identify 'material that is harmful to minors" acceptable practice under the first amendment. However, the Court also demanded that COPA be enjoined and the case be remanded to the Third Circuit, where the Court found COPA created a content-ban on adult transmissions, was overly broad, intrusive, and restrictive in its efforts to protect children from adult speech. (Retrieved from https://www.law.cornell.edu/wex/obscenity)

In the end, the proposed child protections interfered with adult freedom and information exchange. Therefore, Internet restrictions violated First Amendment rights and the COPA never took effect. 
Throughout this book, I have clearly stated my anti-censorship position. However, when I wrote this chapter and searched for children's literature that contained the controversial terms listed in Figure 12.1, I was shocked by the results of some of my searches. I did not search for "pornography" but I found pornographic images and video when I searched for "lesbian; YA novels" or words such as "penis" and "vagina." I expected the results for certain words, but something as simple as "butt" triggered graphic images.

I do not support Internet restrictions nor do I want to limit access to information, but I am concerned about children and young adult exposure to images, videos, and texts that are intended for adults. I would love to think that all parents parent, and all children listen, but this is not the case. Some adults simply do not know what is available online. Some adults are too trusting. And some adults bury their own faces in their own smartphones without noticing their children are visiting obscene spaces.

To create a safe space for youth, there are obscenity laws in place in which the "state" acts in the best interest of the child. In addition, many agencies and entities are working to protect children.

Please read the FBI Parents' Guide to Internet Safety: https://www.fbi.gov/statsservices/publications/parent-guide. Some of you might be thinking- yeah, yeah, whatever, but you should read this document if you have children or work with children in any capacity.

The Digital Future Project has been tracking Internet usage and digital evolution since 1993. If you are interested in data regarding online trends and technology and media usage, visit their site: http://www.digitalcenter.org/

The Pew Research Center provides extensive publications, interactives, presentations, and data sets on media usage and technology as well as expert reports on privacy, regulation, and responsibility. http://www.pewinternet.org/

In a more recent case, the Supreme Court ruled on the content of video games and laws meant to regulate their sales.

Like the protected books, plays, and movies that preceded them, video games communicate ideas-and even social messages-through many familiar literary devices (such as characters, dialogue, plot, and music) and through features distinctive to the medium (such as the player's interaction with the virtual world). That suffices to confer First Amendment protection.

Brown v. Entertainment Merchants Association, 564 U.S. (2011)

This series of cases demonstrates the intricacies of the First Amendment in relation to the intentions of individuals who want to protect children. Whereas the First Amendment appears straightforward, the evolution of children's literature, digital texts, and developing technologies push against "community standards." But whose community decides? 


\section{Public Library Rulings}

As an elaboration on our Constitutionally protected First Amendment rights, the American Library Association developed the Library Bill of Rights to support local libraries and patrons exert their freedom of choice.

The American Library Association affirms that all libraries are forums for information and ideas, and that the following basic policies should guide their services.

I. Books and other library resources should be provided for the interest, information, and enlightenment of all people of the community the library serves. Materials should not be excluded because of the origin, background, or views of those contributing to their creation.

II. Libraries should provide materials and information presenting all points of view on current and historical issues. Materials should not be proscribed or removed because of partisan or doctrinal disapproval.

III. Libraries should challenge censorship in the fulfillment of their responsibility to provide information and enlightenment.

IV. Libraries should cooperate with all persons and groups concerned with resisting abridgment of free expression and free access to ideas.

V. A person's right to use a library should not be denied or abridged because of origin, age, background, or views.

VI. Libraries which make exhibit spaces and meeting rooms available to the public they serve should make such facilities available on an equitable basis, regardless of the beliefs or affiliations of individuals or groups requesting their use.

Adopted June 19, 1939, by the ALA Council; amended October 14, 1944; June 18, 1948; February 2, 1961; June 27, 1967; January 23, 1980; inclusion of "age" reaffirmed January 23, 1996. (Retrieved from http://www.ala.org/advocacy/intfreedom/librarybill) 
Children have a right to read and the authors/illustrators have a right to create, but there is a circuitous route to the point where the two meet.

Although students have rights, so do teachers, administrators, and schools. School librarians are not required to purchase all of the books ever written; therefore, a librarian makes choices within the constraints of the budget and the curriculum. Teachers also make choices about the books they choose to bring into their classrooms. Similarly, administrators use blockers and controls to regulate Internet access and the types of materials students can view on school computers.

Outside of school, children can access books and other media through public libraries and bookstores. Similar to school libraries, the catalog of books depends on the library, bookstore, or youth's budget. Libraries also use Internet controls to block certain content.

Parents exert their influence in out-of-school contexts as well. For example, juveniles cannot obtain library cards without their parents or guardians' permission. Youth may also have difficulty visiting a library or bookstore (online or brick and mortar) due to transportation constraints, limited Internet access, or financial reasons.

The publishing industry also exerts control over what children read. Editors choose which books to develop. Production logistics restrict forms and materials. Marketing and publicity campaigns highlight particular authors, illustrators, or texts. Then reviewers and critics share their opinions. These factors, and others, impact librarians or teachers' choices.

By the time books or other media get into children's hands, the books have made it through layers of review, critique, and selection. Therefore, youth make choices within parameters.

In spite of protective roadblocks, books and media can be subjected to additional challenges. In these cases, the challenge begins at the library.

For a rundown of the most frequently challenged books, check these out:

Read the American Library Association's (ALA) list of the Top Ten Challenged Books by Decade. http://www.ala.org/bbooks/frequentlychallengedbooks/top10

Read the ALA's list of most challenged authors. http://www.ala.org/bbooks/frequentlychallengedbooks/challengedauthors Read the ALA's list of the most challenged authors of color. http://www.ala.org/bbooks/frequentlychallengedbooks/challengedauthors/ authorsofcolor

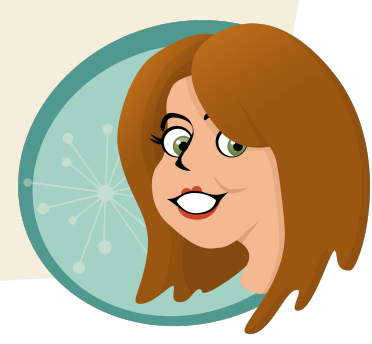




\section{The Challenging Process}

The Office for Intellectual Freedom of the American Library Association provides extensive information about challenges and how libraries should handle them. To be very clear, the library does not ban books. In fact, the library's central tenets are freedom and access to information. Yet, intellectual freedom and the right to express opinions work both ways. Therefore, the library created a process to allow patrons to express their concerns and file complaints.

I repeat - the library does not ban books. In fact, the American Library Association and many other coalitions, associations, and centers have joined together to fight censorship and celebrate the freedom to read (See http://www.bannedbooksweek.org/about).

Since 1982, September marks the month for Banned Books Week. Libraries, bookstores, and other venues sponsor film festivals, workshops, lectures, and virtual read outs to promote the freedom to read and the right to choose

(See http://www.ala.org/bbooks/bannedbooksweek/events/virtualreadout).

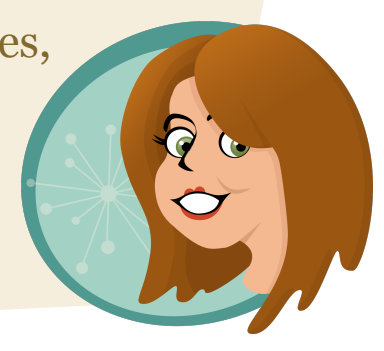

\section{If a patron finds a book to be of concern, he or she may express his or her objection in a number of ways:}

- Expression of Concern. An inquiry that has judgmental overtones.

- Oral Complaint. An oral challenge to the presence and/or appropriateness of the material in question.

- Written Complaint. A formal, written complaint filed with the institution (library, school, etc.), challenging the presence and/or appropriateness of specific material.

- Public Attack. A publicly disseminated statement challenging the value of the material, presented to the media and/or others outside the institutional organization in order to gain public support for further action.

- Censorship. A change in the access status of material based on the content of the work and made by a governing authority or its representatives. Such changes include exclusion, restriction, removal, or age/grade level changes.

(Retrieved from the Intellectual Freedom Committee http://www.ala.org/bbooks/ challengedmaterials) 
A challenge does not necessarily result in a formal complaint, a hearing, or outright censorship. Occasionally, a complaint ends with the mere expression of concern. On other occasions the challenge is pursued. The American Library Association provides suggested policies and procedures for dealing with book challenges and it offers advice for librarians who must oversee collections and respond to complaints (see http://www.ala.org/bbooks/ challengedmaterials/support).

For those who are particularly interested in the library's rationale for defending the freedom of choice or for others interested in media relations, read "Strategies and Tips for Dealing with Challenges to Library Materials." http://www.ala.org/bbooks/challengedmaterials/support/strategies

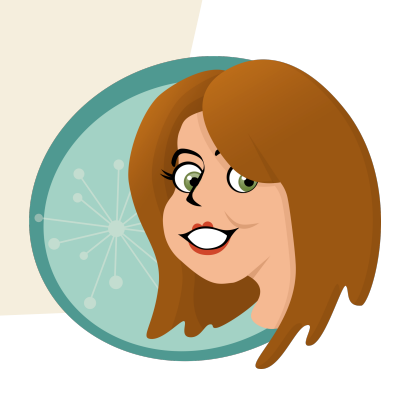

\section{What are they complaining about now?}

Across the thousands of complaints and challenges the ALA registers each year, the following list captures the most common reasons for concern about the content of children's literature:

- Sexually explicit;

- Offensive language;

- Unsuitable to age;

- Violence;

- Homosexuality;

- Religious viewpoints.

These reasons are somewhat generic and function to categorize the complaints rather than describe the specific content. Alternatively, the television, movie, and video game industry have taken different approaches in their content descriptors. 
For example, the music industry created the Parental Advisory Label (PAL) system. In this self-policing program, "individual record companies and artists decide which of their releases should receive a "PAL Notice" indicating that the release contains explicit content....The recording industry's PAL Program lets parents undertake [selection] responsibility for their families and respects the core American value of freedom of expression that tolerates unpopular speech and frowns upon censorship." (Retrieved from https://www.riaa.com/toolsforparents.php?content selector=parental advisory)

I was in high school when a group of moms attempted to ban certain records from music stores. The parents, who were wives of Washington politicians, formed a committee (Parents Music Resource Center) and they pushed the music industry to censor lyrics or ban songs. Eventually, the PMRC exploited their Washington connections (i.e., husbands) and found a way to have their concerns heard by a Senate committee. Famous musicians testified before the Senate, but before any legislative action occurred, the Recording Industry Association of America (RIAA) agreed to a labeling program.

For further details about the "filthy fifteen" records and the PMRC's attempt to ban music, click here: https://en.wikipedia.org/wiki/Parents_Music_Resource_Center

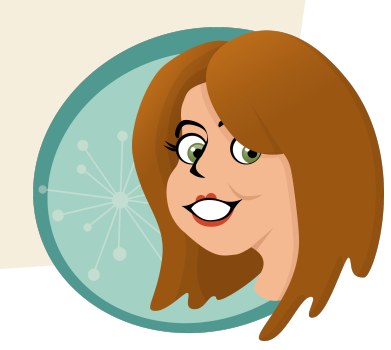

Occasionally, record companies may ask an artist to re-record certain songs or to revise lyrics. Sometimes artists remove songs or re-record edited versions. The artist and recording company determine if the product requires the Recording Industry Association of America/ Parental Advisory Label. Other industries have taken different approaches to label or describe their content.

Is labeling and warning a form of censorship?

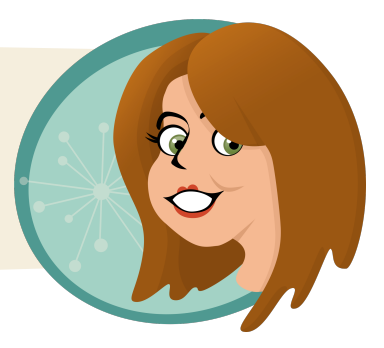


Music (https://www.riaa.com/toolsforparents.php?content selector=parental advisory)

- PAL: Parental Advisory Logo

Television (http://www.tvguidelines.org/ratings.htm)

- D: suggestive dialogue (usually means talks about sex);

- L: course or crude language;

- S: sexual situations;

- V: violence;

- FV: fantasy violence (children's programming only).

Movies (http://filmratings.com/downloads/rating rules.pdf)

- Mature themes;

- Language;

- Depictions of violence;

- Nudity;

- Sensuality;

- Depictions of sexual activity;

- Adults activities (i.e., activities that adults, but not minors, may engage in legally);

- Drug use.

Video Games (http://www.esrb.org/ratings/ratings guide.jsp)

- Alcohol Reference-Reference to and/or images of alcoholic beverages;

- Animated Blood-Discolored and/or unrealistic depictions of blood;

- Blood-Depictions of blood; 
- Blood and Gore-Depictions of blood or the mutilation of body parts;

- Cartoon Violence-Violent actions involving cartoon-like situations and characters. May include violence where a character is unharmed after the action has been inflicted;

- Comic Mischief-Depictions or dialogue involving slapstick or suggestive humor;

- Crude Humor-Depictions or dialogue involving vulgar antics, including "bathroom" humor;

- Drug Reference-Reference to and/or images of illegal drugs;

- Fantasy Violence-Violent actions of a fantasy nature, involving human or non-human characters in situations easily distinguishable from real life;

- Intense Violence-Graphic and realistic-looking depictions of physical conflict. May involve extreme and/or realistic blood, gore, weapons and depictions of human injury and death;

- Language-Mild to moderate use of profanity;

- Lyrics-Mild references to profanity, sexuality, violence, alcohol or drug use in music;

- Mature Humor-Depictions or dialogue involving "adult" humor, including sexual references;

- Nudity-Graphic or prolonged depictions of nudity;

- Partial Nudity-Brief and/or mild depictions of nudity;

- Real Gambling-Player can gamble, including betting or wagering real cash or currency;

- Sexual Content-Non-explicit depictions of sexual behavior, possibly including partial nudity;

- Sexual Themes-References to sex or sexuality;

- Sexual Violence-Depictions of rape or other violent sexual acts;

- Simulated Gambling-Player can gamble without betting or wagering real cash or currency;

- Strong Language-Explicit and/or frequent use of profanity; 
- Strong Lyrics-Explicit and/or frequent references to profanity, sex, violence, alcohol or drug use in music;

- Strong Sexual Content-Explicit and/or frequent depictions of sexual behavior, possibly including nudity;

- Suggestive Themes-Mild provocative references or materials;

- Tobacco Reference-Reference to and/or images of tobacco products;

- Use of Alcohol-The consumption of alcoholic beverages;

- Use of Drugs-The consumption or use of illegal drugs;

- Use of Tobacco-The consumption of tobacco products;

- Violence-Scenes involving aggressive conflict. May contain bloodless dismemberment;

- Violent References-References to violent acts.

Is the entirety of this chapter written in defense of violence and sex? Am I in favor of the obscene?

To the contrary, public school students can read the Bible, Torah, Koran or other religious texts as "literature." Given our First Amendment rights, these texts may be interpreted for their literary qualities.

Public schools can restrict the texts available in school libraries based on budget constraints and curricular goals - all in keeping with the First Amendment as well.

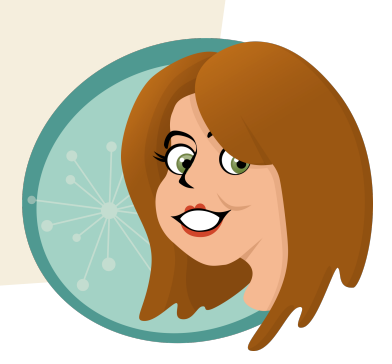


In addition to the extensive list of content descriptors, the video game industry (through the Entertainment Software Rating Board) elected to list the game's interactive elements on its warning labels as well:

- Shares Info-Indicates that personal information provided by the user (e.g., e-mail address, phone number, credit card info, etc.) is shared with third parties;

- Shares Location-Includes the ability to display the user's location to other users of the app;

- Users Interact-Indicates possible exposure to unfiltered/uncensored user-generated content, including user-to-user communications and media sharing via social media and networks. (Retrieved from http://www.esrb.org/ratings/ratings guide.jsp)

To date, books do not come with warning labels or content descriptors. Nor are they subject to a ratings system such as those used with television, movies, video games or fan fiction (see Figure 12.8 for other ratings systems).

However, children's book covers or endpapers

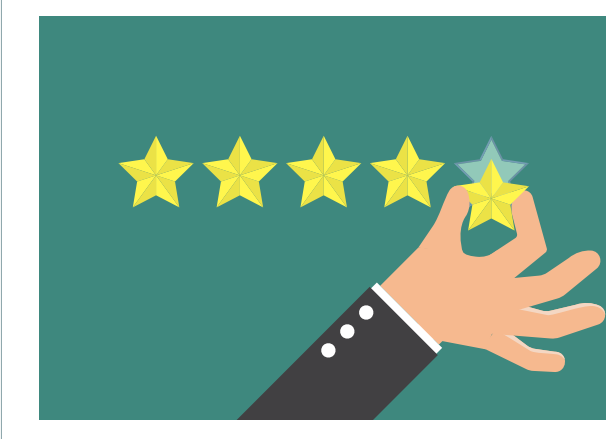

Figure 12.8 Ratings systems for fanfiction, movies, television, music, and video games. may contain information about the age level of the intended reader and a synopsis of the content. Board books, picturebooks, nonfiction, and young adult literature are frequently housed in different sections of a library or bookstore to encourage age-appropriate corralling.

Also, children's literature is heavily reviewed in formal and informal ways, providing librarians, teachers, parents, and other adults with extensive information about a book's content.

School Library Journal (SLJ): http://www.slj.com/\#

SLJ produces resources, services, and reviews for library and education professionals.

However, the materials are also relevant for any adult with an interest in children's and young adult literature. SLJ originated as a print magazine and still exists as such. However, they also produce extensive content, including an amazing network of blogs, that is freely available online.

Molly Wetta.(@mollywetta) curates SLJ’s banned books Pinterest board. Check it out! https://www.pinterest.com/sljournal/banned-books-week/ Click here for SLJ's blog network: http://www.slj.com/slj-blog-network/

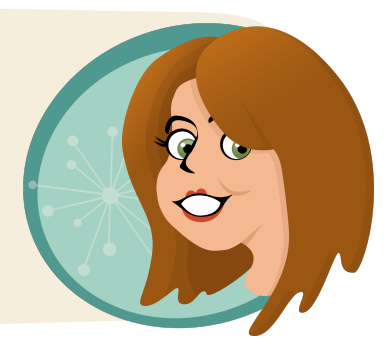


Common Sense Media: https://www.commonsensemedia.org/

Unlike $S L J$, which supports librarians, Common Sense Media originated to rate, educate, and advocate, not for youth's First Amendment rights, but for parents, teachers, and policymakers. According to their mission statement, "Common Sense Media helps families make smart media choices. We offer the largest, most trusted library of independent age-based and educational ratings and reviews for movies, games, apps, TV shows, websites, books, and music" (Retrieved from https://www.commonsensemedia.org/ about-us/our-mission).

Common Sense Media provides detailed information for those individuals who want to know more about the content of children's literature and other forms of media. They also engage in education, policy, and lobbying efforts.

Goodreads: http://www.goodreads.com/

Goodreads is a website in which 40 million users post lists of the books they are reading and survey the lists of their friends and family. In other words, Goodreads is a book recommendation site. Unlike $S L J$ or Common Sense Media, Goodreads is curated by the users. Yes, there are places to access expert opinions (blogs) and author pages, but Goodreads predominantly functions on locating book recommendations based on the users' preferences.

There are thousands of blogs and websites dedicated to children's literature. I featured these three resources because they are popular and consistent sources of information. Yet, I clearly understand there is no way to capture all opinions and satisfy the sensibilities of every child, youth, or concerned adult. 


\section{The Final Word}

In the United States, we don't ban books, but when some people are offended by what they read they often make efforts to limit or restrict what others, especially children, can read, view, watch, and play. The following statement is an excerpt from Supreme Court Justice Antonin Scalia's Opinion of the Court on the matter of video games and vulgarity. He specifically draws connections to children's literature and the Brothers Grimm to make his points.

Certainly the books we give children to read-or read to them when they are younger-contain no shortage of gore. Grimm's Fairy Tales, for example, are grim indeed. As her just deserts for trying to poison Snow White, the wicked queen is made to dance in red hot slippers "till she fell dead on the floor, a sad example of envy and jealousy.” The Complete Brothers Grimm Fairy Tales 198 (2006 ed.). Cinderella's evil stepsisters have their eyes pecked out by doves. Id. , at 95 . And Hansel and Gretel (children!) kill their captor by baking her in an oven. Id. , at 54.

High-school reading lists are full of similar fare. Homer's Odysseus blinds Polyphemus the Cyclops by grinding out his eye with a heated stake. The Odyssey of Homer, Book IX, p. 125 (S. Butcher \& A. Lang transls. 1909) ("Even so did we seize the fiery-pointed brand and whirled it round in his eye, and the blood flowed about the heated bar. And the breath of the flame singed his eyelids and brows all about, as the ball of the eye burnt away, and the roots thereof crackled in the flame"). In the Inferno, Dante and Virgil watch corrupt politicians struggle to stay submerged beneath a lake of boiling pitch, lest they be skewered by devils above the surface. Canto XXI, pp. 187-189 (A. Mandelbaum transl. Bantam Classic ed. 1982). And Golding's Lord of the Flies recounts how a schoolboy called Piggy is savagely murdered by other children while marooned on an island. W. Golding, Lord of the Flies 208-209 (1997 ed.)...

Excerpt from Note 4:

Reading Dante is unquestionably more cultured and intellectually edifying than playing Mortal Kombat. But these cultural and intellectual differences are not constitutional ones. Crudely violent video games, tawdry TV shows, and cheap novels and magazines are no less forms of speech than The Divine Comedy, and restrictions upon them must survive strict scrutiny-a question to which we devote our attention in Part III, infra. Even if we can see in them "nothing of any possible value to society ... , they are as much entitled to the protection of free speech as the best of literature." Winters v. New York, 333 U. S. 507, 510 (1948).

From Justice Scalia's Opinion of the Court, Brown v. Entertainment Merchants Association, 564 U.S., 8-9 (2011).

Did you think I would give Justice Antonin Scalia the final word? Of course not! Although, in this instance, I completely agree with him.

But I do offer Justice Scalia's statement as the second-to-last word because we don't often read about Supreme Court Justices' literary diets nor do we glimpse the breadth of their children's literature knowledge.

For the rest of the court's opinion, click here: https://www.law.cornell.edu/supct/html/ o8-1448.ZO.html\#4ref-- it's a very interesting read.

Children's literature. If Supreme Court Justices read it, you can too. 
In a less litigious and more practical application of readers' rights, I will end this chapter, and this book, with a visual representation of Daniel Pennac's manifesto regarding the Rights of the Reader (Figure 12.9).

Daniel Pennac created this list of reader-considerate practices that disregards well-intentioned adults and focuses on the interaction between a reader and the text-a privileged place where children and youth have choices and select literature for personal, private reasons.

After reading this book, I hope you understand the depth and complexity of children's and young adult literaturethe texts, the writers and illustrators, the markets, the awards, the wars, and everything in between. I also hope you will advocate for children and youth so they are afforded the opportunity to read what they like, when they like, and how they like. Finally, I hope you read children's literature too-it's a big deal!

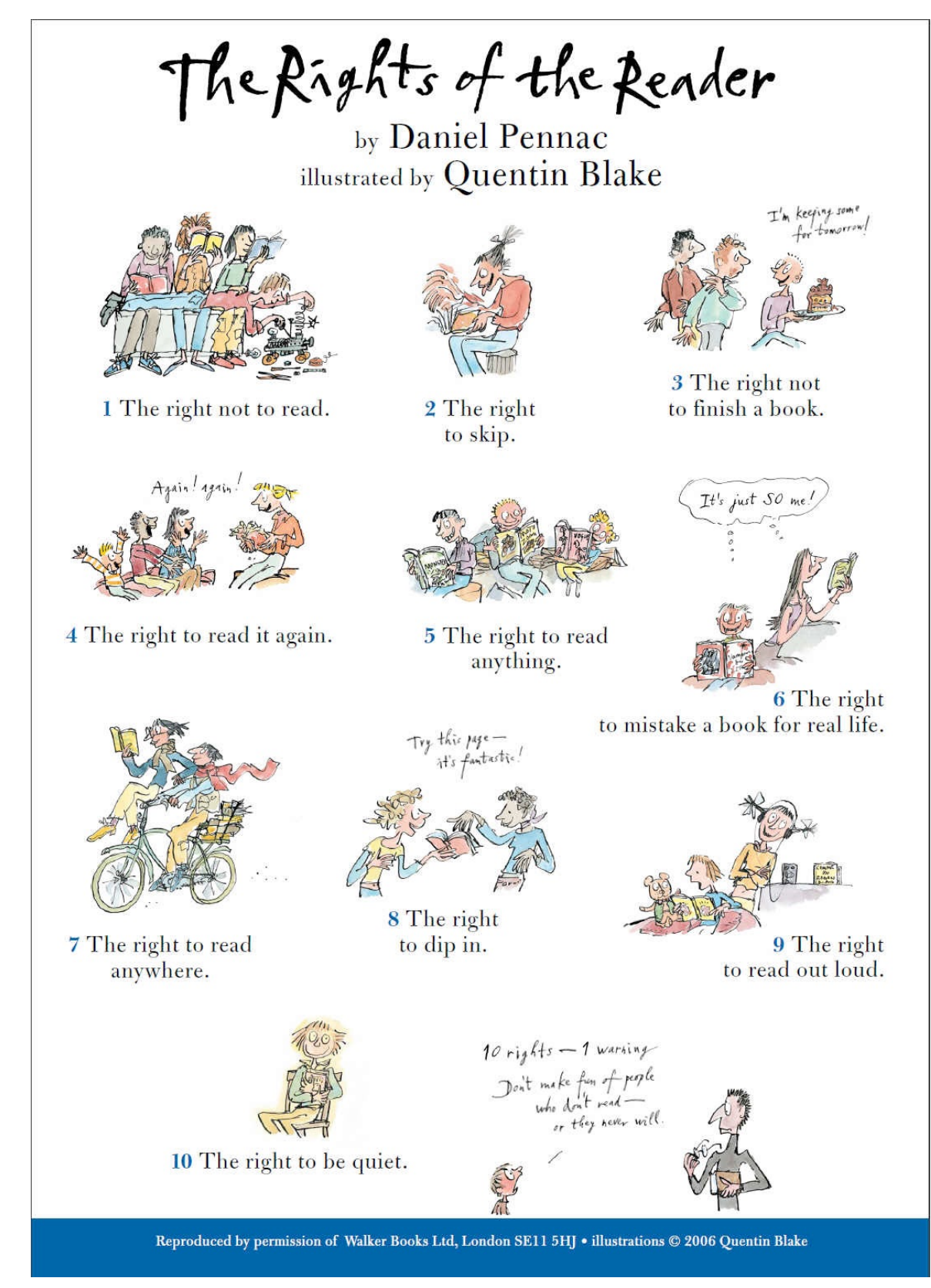

Figure 12.9

I think Daniel Pennac sums up my views perfectly; children are young, but they have rights as readers. The Rights of the Reader by Daniel Pennac, translated by Sarah Hamp Adams, and illustrated by Quentin Blake, 2006, London, UK: Walker Books. Images copyright 2006 by Quentin Blake. 